Scientific journal

PHYSICAL AND MATHEMATICAL EDUCATION

Has been issued since 2013.

Науковий журнал

ФІЗИКО-МАТЕМАТИЧНА ОСВІТА

Видається з 2013.
ISSN 2413-158X (online)

ISSN 2413-1571 (print)

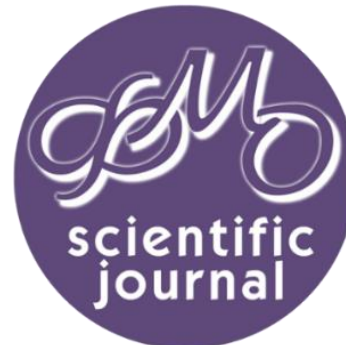

Угрин Ю.О., Британ В.Б., Трембецький М.В. Обгрунтування відстані найкращого бачення. Фізико-математична освіта. 2018. Випуск 1(15). С. 118-121.

Uhryn Yu., Brytan V., Trembetskyi M. Reasoning Of The Most Distinct Vision Distance. Physical and Mathematical Education. 2018. Issue 1(15). P. 118-121.

Удк 53.03/.09, 535-3/-9

Yu.O. Uhryn, V.B. Brytan ${ }^{1}$, M.V. Trembetskyi Ivan Franko Drohobych Pedagogical University, Ukraine ${ }^{1}$ vbrytan2@gmail.com

DOI 10.31110/2413-1571-2018-015-1-020

\title{
REASONING OF THE MOST DISTINCT VISION DISTANCE
}

Abstract. Examines the reasons for the establishment of most distinct vision distance. It is shown that in textbooks on physics and Biophysics there is a full explanation of this concept. It is proved that the blur of the point image on the retina decreases when removing points from the eyes and practically stops its decrease, when the deletion reaches about $10 \mathrm{~cm}$ taking into account calculations for the phenomenon of the spherical surface refraction neuraxial rays.

The conclusion that the most clear distance vision is the optimal distance that a valid low when a good enough linear resolution and, at the same time large enough to form images of paraxial rays.

The three major ideas concerning this problem are distinguished:

The lens equation for nonparaxial ray are found.

It is shown that even in the case of unlimited re duking ability of focal length of human eye crystalline lens, the vision will not be perfect because refraction nature of spherical surface for nonparaxial rays. If an object is located too close to the eye, then image is formed by nonparaxial rays giving a lot images on the retina of each point of the object. As the result, the image is blurred. If an object is too far from the eye, another problem appears: liner resolution decreases, so the images of different points of the object join into one point.

It is shown that existence of the most distinct vision distance due to not biology nature of the human eye but only physics nature of spherical surface refraction and circular aperture diffraction.

Keywords: the most clear distance vision, linear resolution, angular resolution, paraxial beam, separately beam.

Introduction. The authors of the physics textbooks do not pay sufficient attention to the problem of the different distances of view. Often this subject takes a few lines of text, or authors, only arguing the fact that this distance is about $25 \mathrm{~cm}$ [2]. However, some authors try to explain the origin of this distance (this figure), but these explanations seem to us to be not quite exhaustive. On this topic we can distinguish three main ideas. First, the most clear distance vision was formed with the process of evolution by studying items in our hands [4,5], or production activities with the curved sleeves [1]. The second idea is that in order to see the object so far, the eyes are not pushed $[8,9]$. In our opinion, the most adequate expression is that the clearest distance vision is bounded from below, the inability of the visual object to see objects closer to a certain distance [3,7]. This failure is caused by the failure of the crystal lens to increase its convexity (reducing its focal length), sufficient to get too close to the image of the object hit the retina of the eye.

We will show that there is no need in the above-mentioned ability of the eye to decrease its focal length smaller than a certain value. If the crystalline lens can even reduce the focal length, it will not improve the details of the object. Only the spherical surface refractive nature restricts the type of object that is too close to the eye.

Physical model and calculations. Suppose that the optimal distance of the object to which the eye distinguishes all the parts of the object exists, therefore there is the clearest distance vision. Let the object is at this distance. Determine what problems can occur when the object distance is greater than most of the different distances of vision, and when it is coming. Aggravation of vision, which occurs when you delete an object with the eye, obvious that the linear resolution is reduced. It is known that for the eyes as for the lens, the minimum angle hanging from the two closest points for which they are allowed equal to [2]:

$$
\alpha_{m}=1,22 \frac{\lambda}{d}
$$

where is the wavelength of light, hole diameter (box of eye - pupil). 
For eyes, this angle being a constant independent on the distance of these two points from the eyes. Therefore, the angular resolution of the eye is constant. On the contrary, the linear resolution depends on the distance of these two points from the eyes: with the decrease of its linear resolution.

Thus, if the eye is far from the object, its linear resolution is less.

What problems arise when the object is approaching to the eye? At first glance it seems that a corresponding increase in linear resolution will lead to improved vision. However, at the same time, the angle between the rays and the axis of the eye is increased, and the beam becomes neuraxial. Namely, in the formation of the image, in addition to paraxial, rays neuraxial participate. Because neuraxial rays are refracted by a lens stronger than the paraxial, real image point, which appears on the screen (retina), is not a point but a segment, so the image of the object is blurred.

Show it with the help of calculations. First, find the equation of depreciating lenses for ray striker for a lens with an angle to the axis (Fig.1).

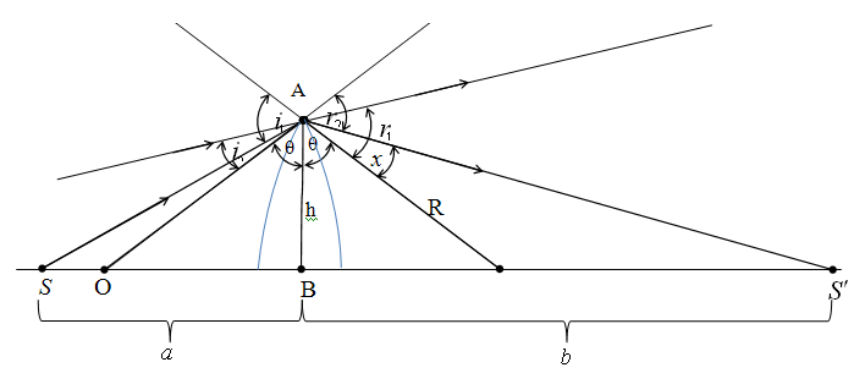

Fig. 1. Napilasya refraction of rays in the lens - the distance from the lens to the point - the object, - distance from image to lens, is the radius of the lens, the radius of curvature of the lens surface, the angles of incidence and refraction for the first lens surface, respectively, is the same for the second surface, $\vartheta$ is the angle between the normal to the surface of refraction and the normal to the axis, is the angle between the refracted ray and the normal to the first surface of refraction.

By applying the law of refraction for both surfaces of the refractive lens, we have:

$$
\begin{aligned}
& \frac{\sin i_{1}}{\sin r_{1}}=n, \\
& \frac{\sin i_{2}}{\sin r_{2}}=\frac{1}{n},
\end{aligned}
$$

with the refractive index of the lens.

From figure 1 and taking into account the theorem of sine, which will be used for the triangle, we get:

$$
\begin{gathered}
i+2 \theta+\sin \left(\frac{a-R}{R} \sin \alpha\right)=\pi, \\
r_{2}+2 \theta+x=\pi, \\
\theta=\operatorname{arctg} \frac{R}{h}, \\
\alpha=\operatorname{arctg} \frac{h}{a} .
\end{gathered}
$$

After the last six equations and triangle equation for beam shows which incidents should be a thin double-convex lens with an angle of axis:

$$
b=-\operatorname{atg} \alpha \cdot \operatorname{tg}\left[\operatorname{arctg}\left(\frac{R}{\operatorname{atg} \alpha}\right)+\arcsin \left(n \sin \left(2 \operatorname{arctg}\left(\frac{R}{\operatorname{atg} \alpha}\right)+\arcsin \left(\frac{1}{n} \sin \left(2 \operatorname{arctg}\left(\frac{R}{\operatorname{atg} \alpha}\right)+\arcsin \left(\frac{a-R}{R} \sin \alpha\right)\right)\right)\right)\right)\right]
$$

Now we can use this equation to calculate the distance of the image points lying on the axis of the eyes with different distances of the object. The axis of the optical system was modeled by the convex lens (the retina) at a distance of $25 \mathrm{~mm}$ from the lens [9].

The maximum angle between the axis and the incident beam is determined by the radius of the hole (pupil). The table shows the results of the calculation of the distance image formed by the paraxial () and neuraxial (mm) shown rays. Different radii of curvature in this table take into account the location of the eyes, which requires that the image of the object to be deleted at any distance, hit the retina.

Table. - distance from the eye to the object, the radius of curvature of the lens surface, which modulates the refractive system of the eye, the distance from image to lens (the retina), is the radius of the lens (the radius of the pupil), - blur the point image.

\begin{tabular}{|c|c|c|c|c|}
\hline \multirow{2}{*}{$a(\mathrm{~mm})$} & \multirow{2}{*}{$R(\mathrm{~mm})$} & \multicolumn{2}{|c|}{$b(\mathrm{~mm})$} & \multirow{2}{*}{$\Delta b(\mathrm{~mm})$} \\
\cline { 2 - 5 } & & with $h=0$ & with $h=2 \mathrm{~mm}$ & 3,21 \\
\hline 20 & 6,67 & 25 & 21,79 & 1,26 \\
\hline 50 & 10,0 & 25 & 23,74 & 0,81 \\
\hline 100 & 12,0 & 25 & 24,19 & \\
\hline
\end{tabular}




\begin{tabular}{|c|c|c|c|c|}
\hline 200 & 13,3 & 25 & 24,25 & 0,75 \\
\hline 300 & 13,8 & 25 & 24,29 & 0,71 \\
\hline
\end{tabular}

As can be seen from the table, drawing a point close to the eye, leads to differences that can be customized, which means that the point image is more blurred. The dependence on the distance to the object shown in figure 2 . We see that, starting from a distance of $\mathrm{cm}$, blur of image is not reduced.

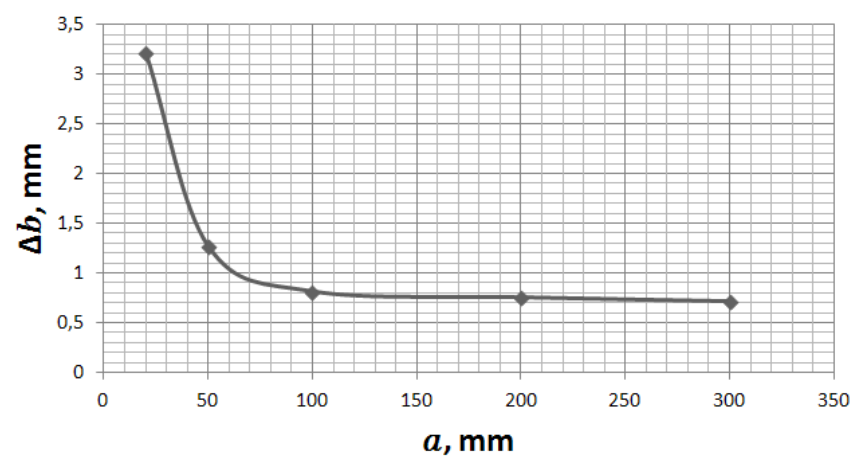

Fig. 2. The dependence of the blur spot image the distance of the point from the eye

Thus, we can Express this distance as the most clear distance vision. Indeed, only a distance of $10 \mathrm{~cm}$ is the distance of clear sight for children. With age, this distance gradually increases because the crystalline lens loses its elasticity and remains stretched, despite the fact that the ciliary muscle is strained, and too large a radius of curvature leads to the pass retinal images (Fig.3).

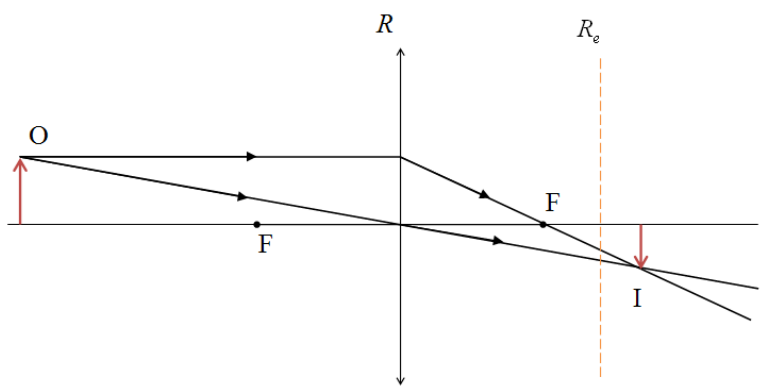

Fig. 3. Modeling hyperopia. $O$ - object, $R$ is the refractive system of the eye, $I$ is the image of the object is the retina, $F$-focus. Refracting system of the eye cannot reduce the focal distance so the image caught in the retina.

Conclusions. We can conclude that the most clear distance vision is the optimal distance to be small enough for a good linear resolution and, at the same time to be large enough to form an image using paraxial rays. The existence of this distance is due only to the nature of the spherical refraction surface and diffraction of circular aperture. It is clear that this distance exists even for perfect eyes - eye opportunity for any small accommodation. Then, the ability of placing a lower bound the most perfect distance vision, but quite the contrary, the most clear distance vision restricts the possibilities for accommodation. With regard to the placement at a distance less than $10 \mathrm{~cm}$, it is not necessary, and this ability of the human eye did not appear as it is in nature, when some of the activities of living organisms have not evolved with the evolution, because there they were not needed.

\section{References}

1. Bushok H. F., Venher Y. F. Kurs fizyky u 3 knyhakh. Knyha 3. Optyka. Fizyka atoma ta atomnoho yadra [Physics course in 3 books Book 3. Optics. Atomic and nuclear Physics]. Kyiv: Lybid. (2003).

2. Kucheruk I. M., Horbachuk I. T. Zahalnyi kurs fizyky u 3 tomakh. Optyka, Kvantova fizyka [General Physics course in 3 volumes. Optics, Quantum Physics]. Kyiv: Tekhnika. (2006).

3. Ohanian H. C. Physics. New-York - London: W.W.Norton \& Company. (1985).

4. Remisov A. N., Maksina A. H.,Potapenko A. Y. Meditsinskaya I biologicheskaya fizika [Medical and biological Physics]. Moskva: Vysshaya shkola. (2003).

5. Shvetz Y. Y., Nebesnyuk O. Y., Nikonova Z. A., Nikonova A. O. Biofizyka. Navchalnyi posibnyk [Biophysics. Educational textbook]. Zaporizhzhya: ZDIA. (2008).

6. Sivukhin D. V. Obshchiy kurs fiziki. Uchebnoe posobie: Dlya vuzov V 5t. T. IV. Optika.[General Physics course. Educational textbook for Universities in 5 vol., vol. IV. Optics]. Moskva: FIZMATLIT. (2005).

7. Tipler P. A. Physics. New-York: Worth Publisher Incorporation. (1982).

8. Tymanyuk V. A., Zhyvotova E. N. Byofyzyka. Uchebnyk dlya studentov vuzov [Biophysics. Textbook for University students]. Kharkov: Zolotye stranytsy. (2003).

9. Yemchyk L. F., Kmit Y. M. Medychna i biolohichna fizyka: pidruchnyk [Medical and biological Physic: Textbook]. Lviv: Svit. (2003). 
Анотація. Досліджено причини формування відстані найкращого бачення. Показано, що в навчальних підручниках з фізики і біофізики немає вичерпного пояснення цієї величини. За допомогою обчислень для явища заломлення сферичною поверхнею непараксіальних променів доведено, що розпливчатість зображення точки на сітківці ока людини зменшується з віддаленням цієї точки від ока і практично перестає зменшуватись за відстані від ока близько $10 \mathrm{~cm}$. Зроблено висновок, що відстань найкращого бачення - це оптимальна відстань, яка є прийнятно малою для того, щоб була достатньою лінійна роздільна здатність і водночас досить великою для того, щоб зображення кожної точки предмета утворювалось на сітківці від перетину параксіальних променів.

Щодо чієї проблеми можна виділити три головні ідеї:

Знайдено формули лінзи для непараксіальних променів.

Показано, що навіть у випадку необмеженої здатності кристалика ока людини до зменшення своєї фокусної відстані, бачення не буде досконалим внаслідок природи заломлення непараксіальних променів сферичною поверхнею. якщо предмет розміщений надто близько до ока, то зображення формується непараксіальними променями, що спричиняє виникнення багатьох зображень кожної точки на сітківці ока. В результаті зображення розпливається. якщо ж предмет знаходиться надто далеко, від ока, виникає інша проблема: зменшується лінійне розділення і тоді зображення різних точок предмета зливаються в одну.

Показано, що існування відстані найкращого бачення обумовлено не біологічною природою людського ока, а саме, фрізичною природою заломлення на сферичній поверхні та дифракції на круглому отворі.

Ключові слова: відстань найкращого бачення, акомодація, лінійна роздільна здатність, кутова роздільна здатність, параксіальний промінь, непараксіальний промінь. 